\title{
Ocena ranljivosti prsti in vegetacije
}

\author{
Barbara Lampič \\ Dr., Oddelek za geografijo, Filozofska fakulteta, Univerza v Ljubljani, \\ Aškerčeva 2, 1000 Ljubljana, Slovenija \\ e-mail: barbara.lampic@uni-lj.si
}

\section{Izvleček}

Uporaba metodologije za izdelavo študij ranljivosti okolja je prikazana na primeru dveh pokrajinotvornih sestavin, prsti in naravne vegetacije. Ocena ranljivosti okolja z vidika posamezne sestavine okolja je lahko prilagojena različnim prostorskim nivojem, manjšim pokrajinskoekološkim enotam ali večjim pokrajinskoekološkim tipom. Ob ustrezni podatkovni podpori lahko po enotah dokaj natančno opredelimo končno oceno ranljivosti okolja, pri pokrajinskih tipih pa prihaja do večjih posploševanj, vendar nam kljub temu omogočajo vpogled v stanje naravnega okolja, stopnjo intenzivnosti antropogenih pritiskov in končno oceno ranljivosti na nivoju celotne države.

Ključne besede: ranljivost okolja, Slovenija, pokrajinotvorne sestavine, prst, naravna vegetacija, gozd, pokrajinskoekološke enote, pokrajinskoekološki tipi, metodologija

\section{Evaluation of the Vulnerability of Soils and Vegetation}

\begin{abstract}
Application of methodology for environmental vulnerability studies of two landscape-forming components, soils and natural vegetation, is presented. Evaluation of environmental vulnerability from the view of particular landscape-forming component can be adjusted to different spatial levels: smaller landscape-ecological units or larger, but still rather homogeneous landscape-ecological types. With sufficient data it is possible quite precisely to evaluate environmental vulnerability on the level of landscape units. On the level of landscape-ecological types the generalisation is much more significant. Despite this the environmental vulnerability studies give us overview over the state of the environment and the impact of human pressures.
\end{abstract}

Key words: environmental vulnerability, Slovenia, landscape-forming components, soil, natural vegetation, forest, landscape-ecological units, landscape-ecological types, methodology 


\section{UVOD}

Analize ocene ranljivosti okolja, ki so odvisne tako od naravnih značilnosti okolja - regeneracijskih in nevtralizacijskih sposobnosti, kot tudi od že dosežene stopnje antropogenih obremenitev, se v skladu z zakonskimi zahtevami izvajajo na prostorsko predhodno oblikovanih homogenih območjih. Za potrebe sonaravnega prostorskega razvoja oziroma za načrtovanje posameznih posegov $\mathrm{v}$ prostor, pa je pomembna tudi notranja struktura ranljivosti okolja proučevanega območja - ranljivost posameznih pokrajinotvornih sestavin (reliefa, prsti, naravne vegetacije (gozd), vode, zraka).

Ocena ranljivosti prsti in naravne vegetacije tako $\mathrm{v}$ študijah ranljivosti okolja predstavlja le segment proučevanja ranljivosti okolja kot celote. Za načrtovanje posegov $\mathrm{v}$ prostor je dejansko uporaben nivo proučevanja kar najmanjša homogena pokrajinska enota, medtem ko se je ocena ranljivosti okolja za celotno Slovenijo po posameznih značilnih pokrajinskih tipih pokazala kot zelo primerna za ugotavljanje stanja in vrednotenje naravnih pokrajinskih razlik in razlik v stopnji antropogenih obremenitev na nivoju celotne države. So pa pokrajinski tipi odločno preobsežne prostorske enote za uporabo rezultatov ocene ranljivosti okolja v prostorskem načrtovanju.

Uporaba metodološke zasnove za izdelavo študij ranljivosti okolja, ki jo je skupina geografov skupaj s strokovnjaki drugih strok od leta 1994 oblikovala, dopolnjevala in prilagajala tako potrebam uporabnikov - načrtovalcev razvoja kot tudi obstoječim dostopnim informacijam $\mathrm{v}$ prostoru, bo $\mathrm{v}$ prispevku prikazana na primeru dveh pokrajinotvornih sestavin - prsti in naravne vegetacije.

Prst in vegetacija sta kot primer uporabe metodologije ranljivosti okolja izbrani predvsem zato, ker je razpoložljivost podatkov za izvedbo posameznih faz študije ranljivosti za vsak element zelo različna. Pri prsteh je zaradi dokončno izdelane pedološke karte Slovenije (v merilu 1:25.000) na voljo dovolj podatkov za opredelitev njenih regeneracijskih in nevtralizacijskih sposobnosti, tako za nivo pokrajinskoekoloških enot kot tipov, za oceno dosežene stopnje obremenitve pa so na voljo predvsem posamezni posredni kazalci, dejanskih podatkov o onesnaženosti prsti pa je za tovrstne potrebe še premalo. Ocenjevanje ranljivosti naravne vegetacije - gozda pa se je pokazalo kot bolj zapleteno predvsem v prvi fazi, in sicer pri določanju njegovih regeneracijskih in nevtralizacijskih oziroma samočistilnih sposobnosti. Na drugi strani pa dobro vzpostavljena mreža monitoringa nudi sorazmerno gosto mrežo podatkov (Monitoring razvrednotenja in poškodovanosti gozdov) o dejanski obremenjenosti gozdnega prostora (GIS, 1995). 
Pomembna kvaliteta in prednost predstavljene metodologije študije ranljivosti okolja je njena vsebinska transparentnost in ponovljivost, ki istočasno omogoča primerljivost med različnimi obravnavanimi območji ter preverjanje stanja okolja na izbranem območju v različnih obdobjih.

\section{OCENA RANLJIVOSTI PRSTI}

Enostavna in pregledna, pa hkrati zelo kompleksno zasnovana shema študije ranljivosti okolja (ŠRO) na nivoju pokrajinskoekoloških enot, je predstavljena na primeru ocene ranljivosti okolja $\mathrm{z}$ vidika prsti.

V prvi, najobsežnejši fazi dela, se najprej s pomočjo fizičnogeografskih kazalcev vrednotijo naravne značilnosti prsti. Na podlagi lastnosti prevladujočega tipa prsti v posamezni enoti (potrebna je določena stopnja generalizacije), opredelimo njegove regeneracijske in nevtralizacijske sposobnosti. Samo izjemoma, v primeru enakovredne zastopanosti posameznih tipov prsti, vrednotimo regeneracijske in nevtralizacijske lastnosti prsti za vsak tip prsti ločeno. Obstoječa pedološka karta omogoča prostorsko zelo natančno obravnavo problematike naravnih lastnosti prsti v primeru predvidenih posegov v prostor, ki bodo pomembno vplivali oziroma prizadeli to sestavino okolja.

Poznavanje lastnosti posameznih tipov prsti nam omogoča, da s pomočjo kazalcev globina profila prsti, tekstura prsti, delež organskih snovi v prsti in reakcija prsti, ocenimo regeneracijske in nevtralizacijske sposobnosti prsti. Omenjeni kriteriji za vrednotenje naravnih značilnosti prsti predvsem opredelijo regeneracijske sposobnosti prsti z vidika onesnaženj (in ne toliko v pomenu razvoja prsti po eroziji, usadih).

Sledi še vrednotenje družbenogeografskih kazalcev, s pomočjo katerih ocenimo doseženo stopnjo antropogenih obremenitev okolja $\mathrm{z}$ vidika prsti. Zaradi pomanjkanja ustreznih podatkov, ki bi omogočali ustrezno uporabo neposrednih kazalcev za tovrstno vrednotenje (kot je npr. kazalec onesnaženost prsti), uporabljamo vrsto posrednih kriterijev, ki kažejo na obremenjenost prsti proučevanega območja. Za prsti so odločilni kazalci o kmetijski intenzivnosti, deležu melioriranih površin, deležu pozidanih (in za prsti dokončno izgubljenih) površin, kazalec o onesnaževanju ozračja, ostali posrednih kazalci pa sliko antropogenega obremenjevanja le še dopolnjujejo.

Kako različne lastnosti prevladujočih tipov prsti pomembno vplivajo na regeneracijske in nevtralizacijske sposobnosti prsti, kažeta karti dveh, pokrajinsko povsem različnih območij v Sloveniji - priobalnega dela Slovenije z njenim flišnim zaledjem ter Celjskega polja. 


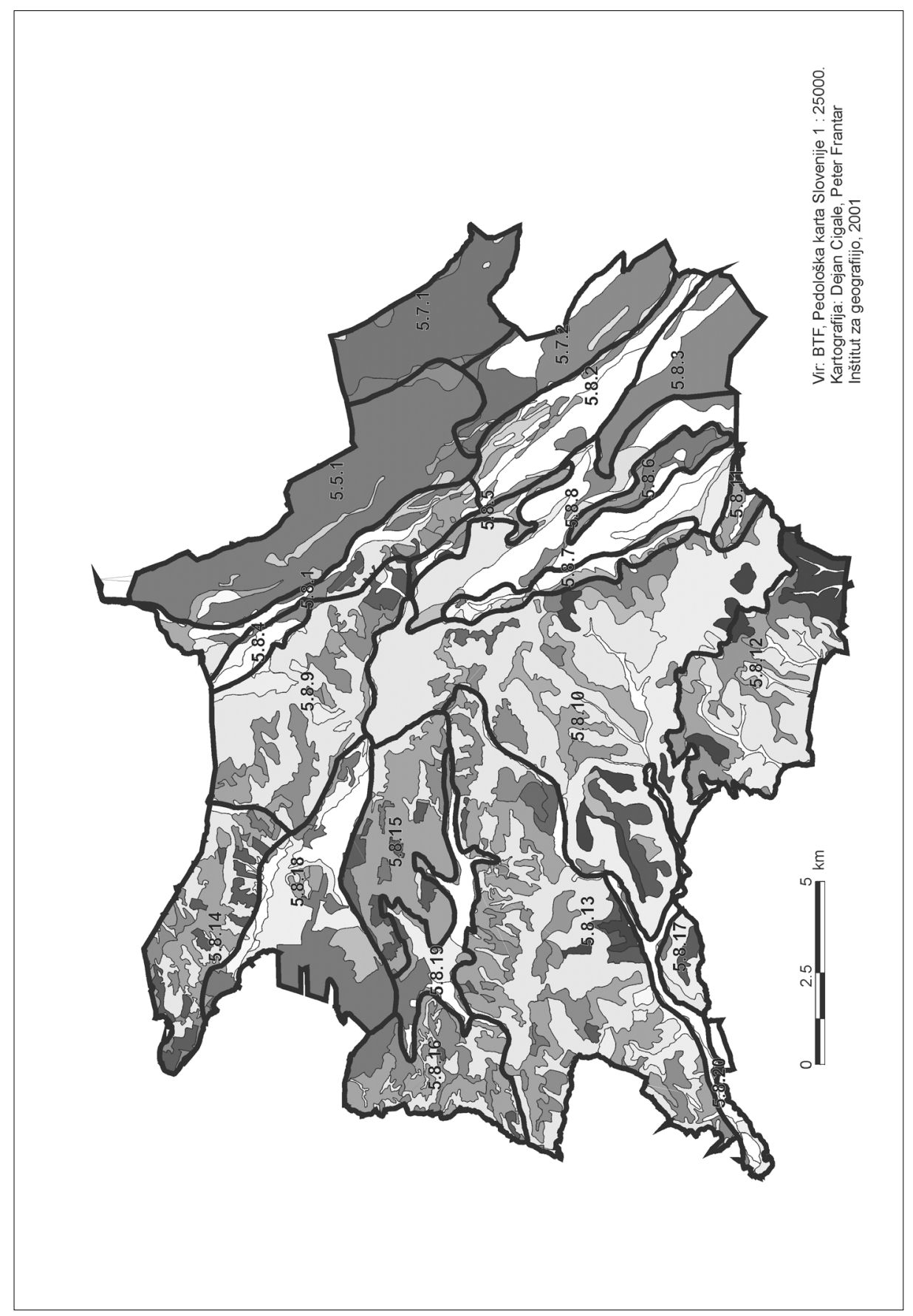

Karta 1:Pedološka karta MOK

622 
Shema izdelave ŠRO za oceno ranljivosti okolja z vidika prsti

\begin{tabular}{|c|c|c|}
\hline $\begin{array}{l}\text { I. Količinska } \\
\text { in kakovostna } \\
\text { analiza }\end{array}$ & $\begin{array}{l}\text { I.a. } \\
\text { Vrednotenje } \\
\text { fizičnogeo- } \\
\text { grafskih } \\
\text { kazalcev }\end{array}$ & $\begin{array}{l}\text { I.a.1. Globina profila prsti } \\
\text { I.a.2. Reakcija prsti } \\
\text { I.a.3. Prisotnost organskih snovi v prsti } \\
\text { I.a.4. Tekstura prsti }\end{array}$ \\
\hline & $\begin{array}{l}\text { I.b. } \\
\text { Vrednotenje } \\
\text { družbenogeo- } \\
\text { grafskih } \\
\text { kazalcev }\end{array}$ & $\begin{array}{l}\text { I.b.1. Onesnaženost prsti } \\
\text { I.b.2. Ocena intenzivnosti kmetijstva na } \\
\text { podlagi rabe tal } \\
\text { I.b.3. Delež melioriranih površin } \\
\text { I.b.4. Živinorejska gostota } \\
\text { I.b.5. Ocena kmetijskega obremenjevanja } \\
\text { na podlagi usmeritve in kapacitete } \\
\text { živinorejskih obratov } \\
\text { I.b.6. Energetska intenzivnost kmetijstva } \\
\text { I.b.7. Delež pozidanih površin } \\
\text { I.b.8. Onesnaževanje zraka - emisije } \\
\text { I.b.9. Cestno omrežje in prometna } \\
\text { obremenjenosti }\end{array}$ \\
\hline $\begin{array}{l}\text { II. Ocena regenera- } \\
\text { cijskih in nevtraliza- } \\
\text { cijskih sposobnosti } \\
\text { okolja }\end{array}$ & \multicolumn{2}{|c|}{ Izhaja iz vrednotenja fizičnogeografskih kazalcev. } \\
\hline $\begin{array}{l}\text { III. Dosežena } \\
\text { stopnja obremenitve } \\
\text { okolja }\end{array}$ & \multicolumn{2}{|c|}{ Izhaja iz vrednotenja družbenogeografskih kazalcev. } \\
\hline $\begin{array}{l}\text { IV. Skupna ocena } \\
\text { ranljivosti okolja }\end{array}$ & \multicolumn{2}{|c|}{$\begin{array}{l}\text { Izhaja iz ocene regeneracijskih in nevtralizacijskih sposobnosti } \\
\text { okolja in skupne ocene ranljivosti okolja. }\end{array}$} \\
\hline
\end{tabular}

V Mestni občini Koper (MOK) prevladujejo prsti z zmernimi regeneracijskimi sposobnostmi, nizke pa imajo enote na vzhodu občine, kjer prevladujejo plitve rendzine. $\mathrm{O}$ zelo visokih regeneracijskih in nevtralizacijskih sposobnosti okolja $\mathrm{z}$ vidika prsti lahko govorimo le $\mathrm{v}$ eni pokrajinski enoti, Nizkem gričevju med Rižano in Badaševico, kjer prevladujejo globoke evtrične prsti.

Primera ocene regeneracijskih in nevtralizacijskih sposobnosti okolja $\mathrm{z}$ vidika prsti na dveh, pokrajinsko povsem različnih območjih, kažeta, kako je regeneracijska sposobnost prsti odvisna od številnih dejavnikov. V MOK, ki je pokrajinsko sila pestra, od priobalnih ravnic do flišnega gričevja $\mathrm{v}$ osrednjem delu ter kraškega zaledja na skrajnem vzhodu občine, so zastopani celo trije pokrajinskoekološki tipi (Širše doline in obalne ravnice v primorskem delu Slovenije, Gričevje v primorskem delu Slovenije in Kras in Podgorski kras). Pokrajinsko veliko bolj homogeno pa je Celjsko polje, ki ga skoraj v celoti lahko uvrstimo v en pokrajinski tip - Medgorske kotline. Kljub temu, da se na 
Barbara Lampič / Dela 18 • 2002 • 619-633 


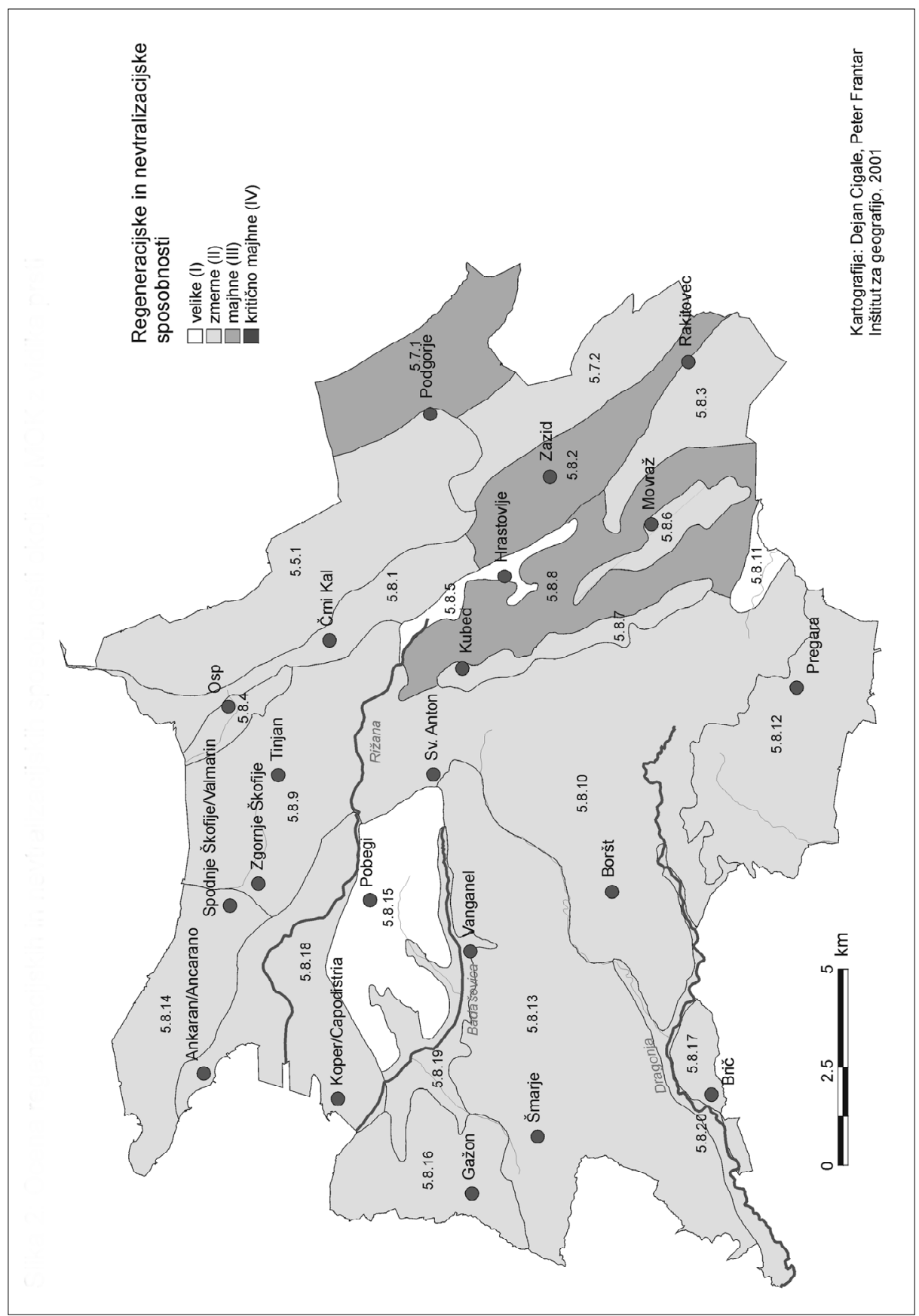

Karta 2: Ocena regeneracijskih in nevtralizacijskih sposobnosti okolja v MOK $z$ vidika prsti 

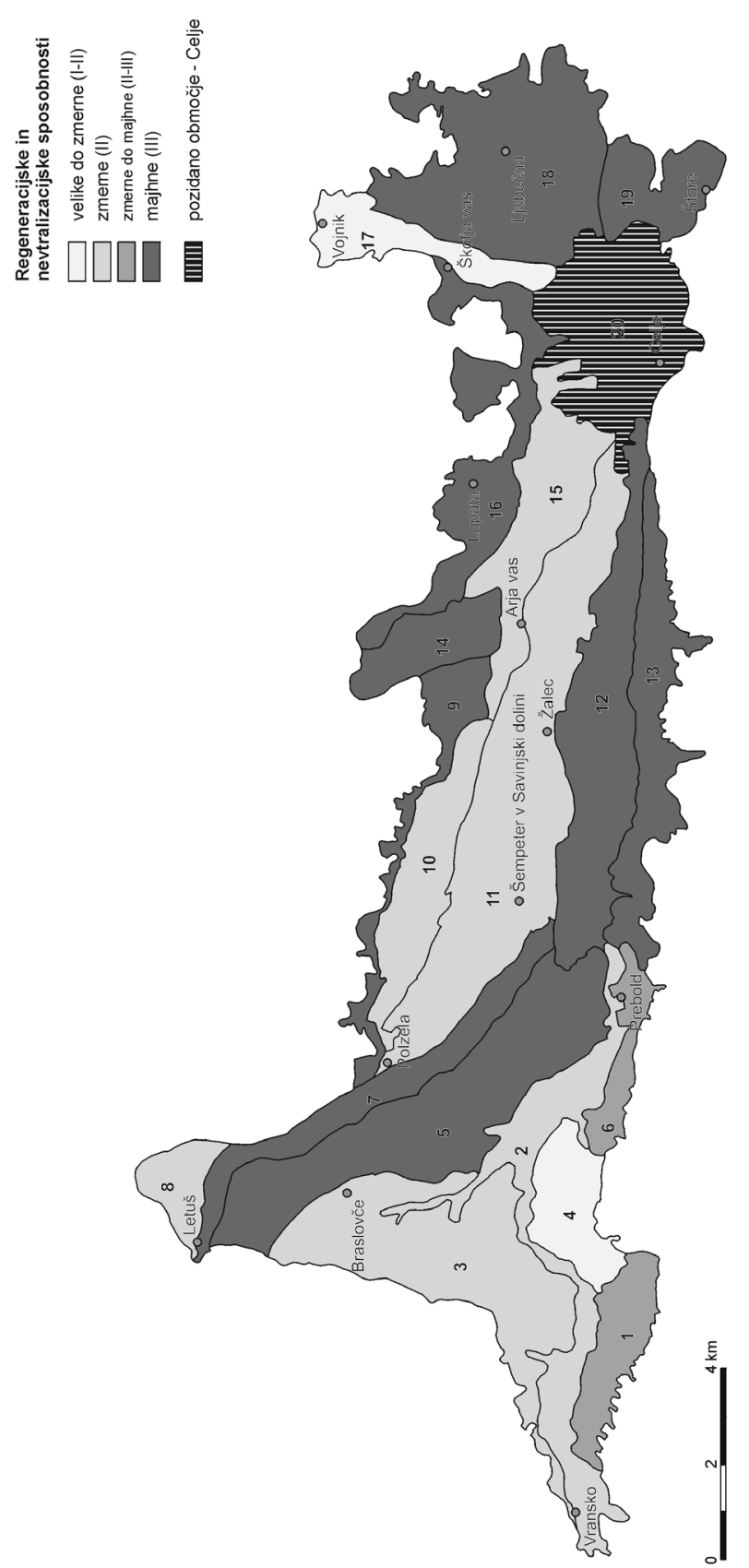

Karta 3: Ocena regeneracijskih in nevtralizacijskih sposobnosti okolja z vidika prsti (na Celjskem polju) 
enem območju (MOK) pojavlja več pokrajinskih tipov, v drugem (Celjskem polju) pa le eden, so regeneracijske in nevtralizacijske sposobnosti prsti na obeh prikazanih območjih tudi notranje precej heterogene. Pedološka karta in poznavanje lastnosti posameznih tipov prsti nam omogoča, da lahko regeneracijske in nevtralizacijske sposobnosti okolja $\mathrm{z}$ vidika prsti opredelimo še bistveno bolj natančno kot le na nivoju pokrajinske enote, kar je predvsem koristno $\mathrm{z}$ vidika konkretnih načrtovalskih posegov.

Zastopanost posameznih tipov prsti $\mathrm{v}$ okviru enega pokrajinskoekološkega tipa je torej lahko zelo heterogena. V Visokogorskem svetu se skoraj izključno pojavljajo rendzine na apnencu in dolomitu ter kamnišča, na Ravninah in širših dolinah v gričevju notranjega dela Slovenije pa so prisotne tako plitve obrečne prsti, oglejena in psevdooglejena tla, distrična ali evtrična rjava tla na ledenodobnih nasutinah rek, itd., skratka prsti, ki se po osnovnih lastnostih med seboj pomembno razlikujejo.

Za opredelitev regeneracijskih in nevtralizacijskih (nosilnih) sposobnosti prsti na nivoju pokrajinskih tipov sta odločilni dve potezi, fizikalno-kemijske lastnosti prsti ter prepustnost prsti za vodo. Ocena dosežene stopnje obremenjenosti prsti temelji na nizu posrednih kazalcev, ki kažejo na stopnjo antropogenih pritiskov na ta pokrajinotvorni element. Med najpomembnejše sodijo kmetijsko obremenjevanje, prometna obremenjenost in onesnaževanje zraka. Vsi omenjeni kriteriji so t.i. sestavljeni kazalci, katerih ocena ali izračun zahteva dobro poznavanje naravnih značilnosti in zakonitosti procesov $\mathrm{v}$ prsteh posameznega tipa pokrajine, oziroma poznavanje procesov in posledic obremenjevanja okolja s posebnim poudarkom na prsteh.

Dobre regeneracijske in nevtralizacijske sposobnosti imajo kambične prsti, ki so dobro razvite in globoke z zelo ugodnimi fizikalno-kemijskimi lastnostmi (reakcija, struktura, etc.).

Nekoliko slabše fizikalno-kemijske lastnosti in s tem sposobnosti za regeneracijo (samočistilne sposobnosti) imajo pretežno antropogene prsti v Medgorskih kotlinah (Ljubljanska, Celjska kotlina), deloma prsti na Ravninah in v širših dolinah gričevja notranjega dela Slovenije (Apaško, Dravsko, Ptujsko in Brežiško polje), Hribovja v pretežno nekarbonatnih kamninah in prsti v Širših dolinah in obalnih ravnicah v primorskem delu Slovenije.

$\mathrm{Na}$ Črnomalskem ravniku nizkega krasa Bele krajine imajo prsti nizke nevtralizacijske sposobnosti, medtem ko so regeneracijske sposobnosti prsti na območju tipov, kjer prevladuje karbonatna matična osnova, izrazito nizke. Zelo plitve, slabo razvite in zato za antropogene vplive zelo občutljive prsti tako prevladujejo v visokogorskem svetu, visokih kraških planotah in hribovju v karbonatnih kamninah, nizkem krasu Notranjske in Dolenjske, Krasu in Podgorskemu krasu ter južnem delu nizkega krasa Bele krajine. Hkrati so te prsti zelo prepustne za vodo. Zelo nizke regeneracijske in nevtralizacijske sposob- 


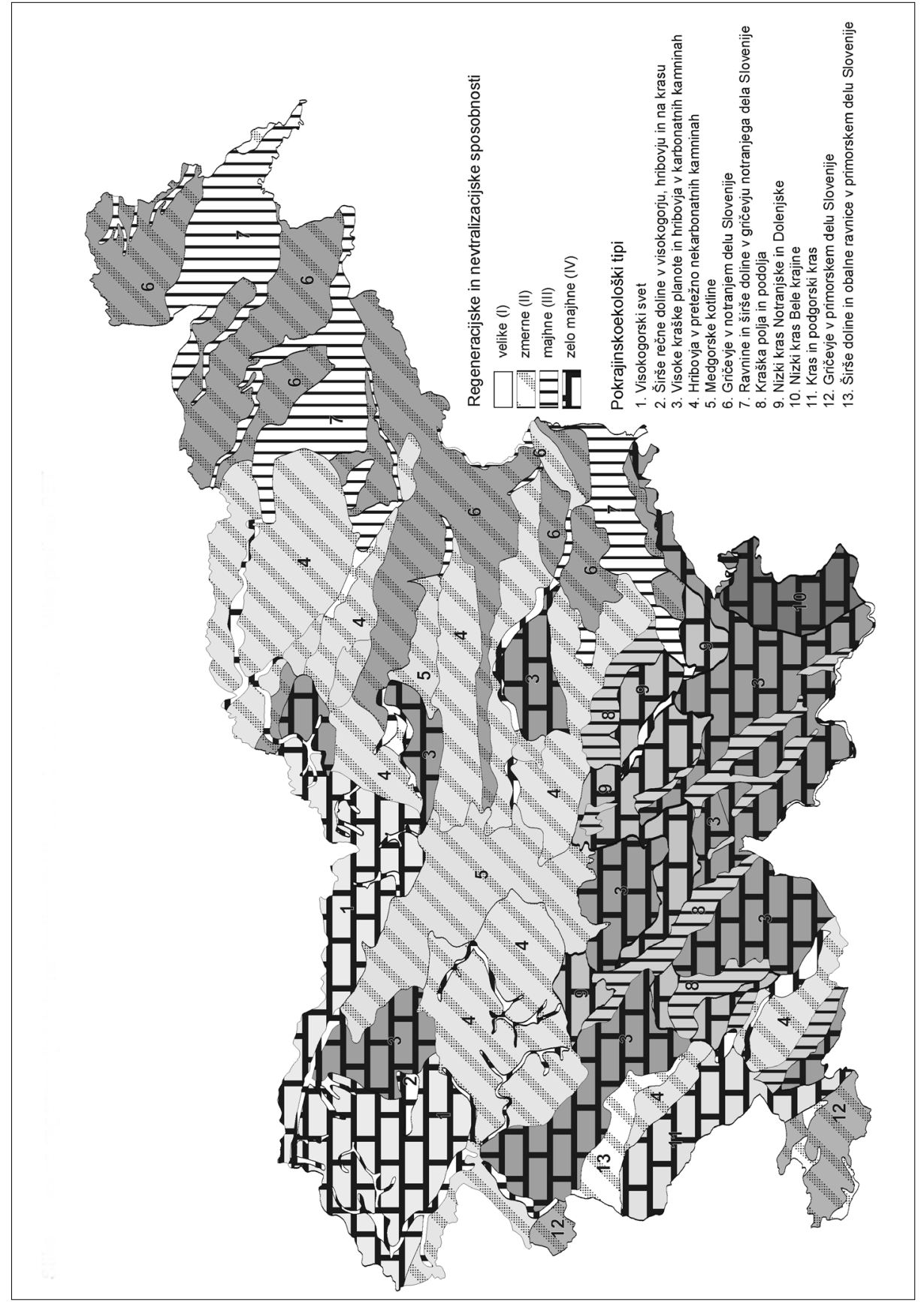

Karta 4: Ocena regeneracijskih in nevtralizacijskih sposobnosti okolja z vidika prsti po PET 
nosti imajo tudi pokrajinski tipi, kjer prevladujejo plitve obrečne prsti in rankerji (širše rečne doline $\mathrm{v}$ visokogorju, hribovju in na krasu in širše doline $\mathrm{v}$ gričevju notranjega dela Slovenije).

V posameznih tipih pokrajine zaradi pestrosti pedološke zgradbe prihaja do tolikšnih razlik, da bi bilo potrebno opredeliti različne razrede znotraj posameznega tipa. Regeneracijske in nevtralizacijske sposobnosti prsti po tipih pokrajine kažejo, da imajo najugodnejše fizikalno-kemijske lastnosti, slabo prepustnost ter posledično precej visoke regeneracijske, nosilne sposobnosti prsti $\mathrm{v}$ Gričevju v notranjem delu Slovenije (zastopane kambične prsti) ter Hribovje v pretežno nekarbonatnih kamninah. V kar šestih tipih pa so te sposobnosti zelo majhne, bodisi zaradi velike prepustnosti prsti, kar je značilno za vse tipe $\mathrm{v}$ pretežno kraških območjih s plitvimi prstmi (Visokogorski svet $\mathrm{z}$ nesklenjenimi prstmi) ali zaradi fizikalno-kemijskih lastnosti prsti.

Ocena dosežene stopnje obremenitve prsti temelji na nizu posrednih kazalcev, ki kažejo na stopnjo antropogenih pritiskov na ta pokrajinotvorni element. Na nivoju tipov sodijo med najpomembnejše kmetijsko obremenjevanje, prometna obremenjenost in onesnaževanje zraka. Neposreden kazalec o dejanski onesnaženosti prsti je za nivo pokrajinskih tipov še neuporaben, saj so trenutno dostopni podatki o onesnaženosti skupaj z rezultati meritev monitoringa onesnaženosti prsti prostorsko preveč omejeni.

Pri oceni končne ranljivosti so se med pokrajinskoekološkimi tipi z vidika prsti kot bolj ranljivi pokazali Visokogorski svet, Širše rečne doline v visokogorju, hribovju in na krasu ter Nizki kras Bele krajine, predvsem zaradi izjemno nizkih samočistilnih sposobnosti ter Medgorske kotline, Ravnine in širše doline v gričevju notranjega dela Slovenije in Širše doline in obalne ravnice v primorskem delu Slovenije zaradi intenzivnosti antropogenega obremenjevanja.

\section{OCENA RANLJIVOSTI NARAVNE VEGETACIJE - GOZDA}

Za razliko od ocenjevanja ranljivosti okolja z vidika prsti, pa je vrednotenje gozdnega prostora s pomočjo metodologije ranljivosti okolja manj transparentno, pri analizi pa je potrebno sodelovanje regionalnih strokovnjakov gozdarske stroke in njihova ekspertna ocena, ki temelji na izbranih sinteznih kazalcih. Vsa leta oblikovanja metodologije študije ranljivosti okolja so potekala prizadevanja in sodelovanja s strokovnjaki-gozdarji, da bi oblikovali uporabno metodologijo ranljivosti okolja z vidika gozda, ki bi na eni strani upoštevala tako regeneracijske sposobnosti naravne vegetacije kot tudi širšo paleto antro- 


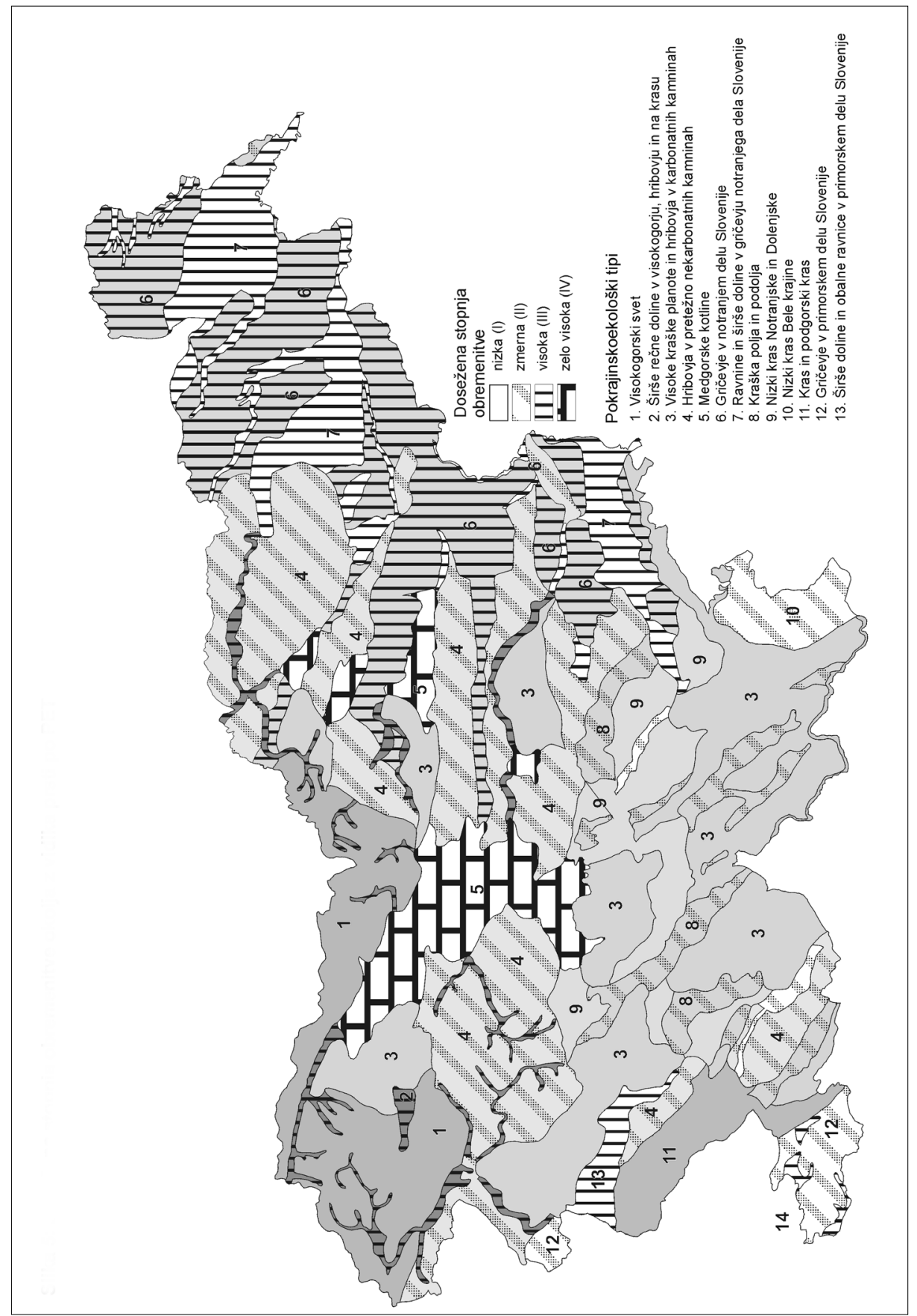

Karta 5: Dosežena stopnja obremenitve okolja z vidika prsti po PET 
pogenih pritiskov. Do dokončno izbranih kazalcev za omenjeni fazi dela ni prišlo, pri konkretnih izdelavah študije pa smo si, kot je bilo že omenjeno, pomagali z regionalnimi strokovnjaki in dobrimi poznavalci lokalnega gozdnega prostora.

Kljub številnim metodološkim dilemam je naravna vegetacija kot pomembna pokrajinotvorna sestavina ostala $\mathrm{v}$ širši shemi študije ranljivosti okolja.

Izdelave študij na konkretnih primerih so pokazale, da je na nivoju pokrajinskoekoloških enot mogoče opredeliti ranljivost gozda z nizom kompleksnih kazalcev. Upoštevati je potrebno ustreznost obsega gozda, ustreznost razmestitve gozda glede na naravne razmere, ustreznost povezanosti gozdnih površin in ustreznost tipa gozda.

Izbor kriterijev je omejen s skopim obsegom podatkov. Prednost takšnega proučevanja gozdnega prostora na določenem območju pa predstavlja poznavanje njegovih značilnosti s strani regionalnih strokovnjakov, hkrati pa so po posameznih območnih enotah zadovoljivo obdelani številni podatki, kar smo v dosedanjih študijah ranljivosti s pridom izkoristili.

Osnovno informacijo o stanju gozda v izbrani pokrajini nam da skupni kazalec o deležu gozda (znotraj posamezne pokrajinskoekološke enote), ki kaže na to, $v$ kakšno pokrajino posegamo. Ali je pokrajinska enota gozdnata, s prevladujočimi značilnostmi gozdnega ekosistema ali pa se gozd pojavlja le $\mathrm{v}$ obliki manjših otokov v sicer kmetijski ali celo urbani pokrajini, kar bistveno vpliva na vlogo gozda v pokrajini oz. delovanje pokrajinskoekološke enote nasploh. Na nižjem prostorskem nivoju proučevanja (pokrajinska enota) je ta informacija še bolj pomembna kot na nivoju pokrajinskoekoloških tipov, saj govorimo o prostorsko zelo omejenih območjih, kjer se vse človekove negativne dejavnosti takoj odražajo v okolju.

Posamezni sintezni kazalci, ki opredeljujejo končno ranljivost okolja $\mathrm{z}$ vidika gozda, pa imajo naslednji pomen:

Ustreznost obsega gozda glede na naravne razmere; Praviloma so pokrajinske enote $\mathrm{z}$ velikim deležem gozda za nove antropogene posege manj ranljive, ni pa pomemben le absoluten obseg gozda, ampak tudi njegov obseg glede na obstoječe naravne razmere. Načeloma naj bi veljalo, da slabši kot so rastni pogoji (za rast kulturnih rastlin), predvsem reliefne, pedološke in klimatske razmere ter večja kot je pogostost različnih destrukcijskih procesov (erozija, denudacija), večji naj bi bil delež gozda.

Ustreznost povezanosti gozdnih površin; Gozd lahko deluje kot sistemski biotop takrat, ko so gozdni kompleksi med seboj ustrezno povezani. To omogoča kroženje materije in pretok energije ter izmenjavo genetskega fonda flore in favne. Manj ko je gozda na nekem območju, bolj je pomembna njegova povezanost. Odločilna je povezanost in sklenjenost tistih gozdov, ki jih 
ločujejo doline, med pobočji preko slemen in povezava med gozdom v povirju in ob strugi hudournikov.

Ustreznost tipa gozda; Zaradi človekovega vpliva (intenzivna sečnja, onesnaževanje, spreminjanje naravnih drevesnih vrst, itd.) se spreminja drevesna sestava in zgradba gozdov. Vse antropogeno pogojene spremembe $\mathrm{v}$ gozdu povzročajo odmik stanja $\mathrm{v}$ gozdu od naravnega optimuma, $\mathrm{s}$ tem pa se povečuje nestabilnost gozda in seveda veča njegova občutljivost, ranljivost. Ta dejavnik vključuje več kriterijev; npr. delež iglavcev v posamezni enoti, starost gozda (odrasel gozd, zarasle površine), zgradba, itd.

Ustreznost razmestitve gozda glede na naravne razmere; Razmestitev gozda je tesno povezana z njegovo funkcijo v prostoru. V enotah, kjer je delež gozda nižji, se pomen ustrezne razmestitve gozda še poveča. Pri manjši gozdnatosti je gozd ohranjen predvsem tam, kjer opravlja pomembne okoljetvorne funkcije (npr. varovalna funkcija). Na primeru razmestitve gozda v Mestni občini Koper se je pokazalo, da je odločilna ohranjenost večjega deleža gozda na severnih ekspozicijah, da pokriva površine z večjimi nakloni, da zarašča povirja hudournikov in obdaja potoke, da so $\mathrm{v}$ dolinah pasovi drevja ob potokih in da obstajajo manjše gozdne zaplate med pretežno kmetijskimi površinami.

Pri izdelavi študije ranljivosti okolja še vedno ostajajo odprta nekatera metodološka vprašanja in dileme. Zavedati se je potrebno velike stopnje generalizacije, kar velja predvsem za ocenjevanje ranljivosti na nivoju pokrajinskih tipov. Pri posameznih sestavinah okolja so pomanjkljivi podatki za določanje regeneracijskih in nevtralizacijskih sposobnosti (npr. gozd, zrak), pri drugih za določanje vplivov različnih človekovih dejavnosti (npr. prsti), kar posledično vodi $\mathrm{k}$ večjemu poudarku na ekspertni oceni.

Kljub vsemu pa so dosedanje izkušnje pokazale na veliko uporabno vrednost takšnega pristopa za načrtovanje bodočih posegov $\mathrm{v}$ prostor, istočasno pa nam takšna metodološka zasnova omogoča številne primerjave znotraj manjših zaključenih območij, pa tudi širše, na nivoju celotne Slovenije.

\section{Literatura:}

Bogataj, N., 1997. Degradacija gozda s posebnim ozirom na metodološko problematiko popisa, magistrsko delo. Mentor: Radinja D., somentor: Hočevar M., Univerza v Ljubljani, Filozofska fakulteta. Ljubljana.

GIS 1995, 1995. Monitoring propadanja gozdov in gozdnih ekosistemov. Priročnik za terensko snemanje podatkov. Gozdarski inštitut Slo., Ljubljana. 
Mikola, D., 2002. Ranljivost Celjskega polja z vidika prsti, diplomska naloga. Mentor: Vovk Korže A., somentor: Lampič B., Univerza v Mariboru, Pedagoška fakulteta. Maribor.

Pedološka karta Slovenije, M 1:25.000. Biotehniška fakulteta.

Repe, B., 2002. Degradacija prsti v Sloveniji, magistrsko delo. Mentor: Lovrenčak F., Univerza v Ljubljani, Filozofska fakulteta. Ljubljana.

Špes, M., Brečko, V., Hočevar, M., Lampič, B., Natek, K., Plut, D., Smrekar, A., Šebenik, I., Šubic, A., Vovk-Korže, A., 1996. Študija ranljivosti okolja, vsebina in metodologija kot osnova za pripravo podzakonskega akta, delovno gradivo. Inštitut za geografijo, Ljubljana.

Špes, M., Cigale, D., Lampič, B., Natek, K., Plut, D., Smrekar, A., Vovk-Korže, A., 1999. Ranljivost okolja kot omejitveni dejavnik prostorskega razvoja Slovenije, zaključno poročilo. Inštitut za geografijo, Ljubljana.

Špes, M., Cigale, D., Lampič, B., Natek, K., Smrekar, A., 2001. Ranljivost okolja na območju mestne občine Koper. Inštitut za geografijo, Ljubljana.

Vovk-Korže, A., 1999. Razširjenost in ekološke značilnosti prsti v dolini Rižane. Annales, Series historia naturalis, 9, 1999, 1. Koper.

Zakon o varstvu okolja. Uradni list RS 32/93, 17.6. 1993.

\section{EVALUATION OF THE VULNERABILITY OF SOILS AND VEGETATION}

\section{Summary}

Evaluations of vulnerability of two landscape-forming elements: soils and natural vegetation (forest), are components of the environmental vulnerability studies.

Evaluation of environmental vulnerability from the view of particular landscape-forming component can be adjusted to different spatial levels, smaller landscape-ecological units or larger, but still rather homogeneous landscapeecological types. With sufficient data, the quality of such study increase significantly, but also in the case of their deficiency, the results are still useful due to the methodological structure of this studies and application of indicators.

With the analysis of the selected indicators, the regenerative and neutralizing capacities of soils and the human burden (impact, pressure) are evaluated. The soil map of Slovenia (in scale 1:25.000) makes a good basis for the evaluation of regenerative capacities of soil. For this purpose four indicators were selected: thickness of soil profile, reaction $(\mathrm{pH})$ of soils, soil organic matter and the texture of soils. On the other hand, the level and intensity of 
human impact on the environment (soils) is much more difficult to define, either with quantitative or qualitative indicators, because the environmental data are insufficient. With various indicators as agricultural intensity (land use, etc.), energy intensity of agriculture, losses of soils, air pollution, traffic intensity, etc., the intensity of human pressures is evaluated. The information about contamination of soils are relatively poor, so this indicator is, due to insufficient data, less important.

Evaluation of vulnerability of natural vegetation (forest) is an example, where the methodology of environmental vulnerability study cannot be used directly. Insufficient data about regenerative capacities of forests and also about environmental burdening are the reasons that expert evaluation is applied. 